\title{
Sosyolojik Yaşamak
}

\author{
DOI: 10.26466/opus.736124
}

\begin{abstract}
Behçet Batur *
* Dr. Öğr. Üyesi, Gaziantep İslam Bilim ve Teknoloji Üniversitesi İslami İlimler Fakültesi Felsefe ve Din Bilimleri Bölümü Din Sosyolojisi Anabilim Dalı E-Posta: behcetbatur@yahoo.com

ORCID: 0000-0001-6965-6313

\section{$\ddot{O} z$}

İnsanoğ lu, toplumsal olarak var olmaya başladığından bu yana kendisinin de bir parçası olduğu toplumsal dünyasın sürekli bir anlama ve açıklama çabasında olmuştur. Başlangıçta daha çok dini ve felsefi düzlemde gerçekleşen bu çaba, zaman içerisinde bilimsel-sosyolojik bir aşamaya ulaşmış ve yaşadığı toplumsal dünyayı artık bilimsel bir şekilde anlamlandırmaya ve açıklamaya devam etmiştir. Toplumsal hayat, insanoğlunun ilk varlı̆̆ından bu yana var olmasına rağmen, insanın içinde yaşadı̆̆ topluma sosyolojik bakış ve kavrayış biçimi modern zamanların bir ürünüdür. Toplumsal hayata ilişkin bilgi edinme çabasının bu yapısal dönüşümü ve kurumsal gelişimi bireyin toplumsal hayatına farklı açılardan bakabilmeyi ve insan hayatın daha bilinçli ve kaliteli bir hale getirmesine katkıda bulunması beklenmektedir. Sosyolojiyi yaşamak, toplumsal hayata dair edinilen bu bilimsel bilginin birey ve toplum hayatına yön verebilmesi demektir. Günümüzde, sosyolojik bilgi, bireyin içinde bulunduğu toplumsal dünyasının pozitif bilgisi olduğundan, bu bilgi son derece önemli bir yaşamsal rehberlik kaynağı konumundadır. Sosyoloji biliminin kurucuları ve genelde tüm sosyologlar yerel veya küresel, kısmi ya da genel olsun giriştikleri tüm çabaları, içinde bulundukları toplumsal dünyanın anlaşılması ve açılanması çabasıdır. İnsanoğlu, antropolojik olarak anlam ve eylem oluşturma kabiliyetine sahip olduğundan ve bu anlam ve eylem oluşturma faaliyeti-toplum özelinde-artık sosyolojik bilginin de ışı̆̆ında oluştuğundan bu anlamda sosyolojinin yaşanabilmesinden söz edilebilir. Kısacası, sosyolojik yaşamak, sosyolojik bilginin insan düşünce ve eylemlerini etkilemesi ve bunlara yön verebilmesi demektir. Bu yönüyle sosyoloji sadece bir okuma ve araştırma etkinliği değil aynı zamanda bir yaşama biçimi olarak karşımıza çıkmaktadır.

Anahtar Kelimeler: Sosyoloji, sosyolojik bilgi, sosyolojik yaşamak 


\title{
Sociological Living
}

\begin{abstract}
Although the history of the views and approaches to understanding and explaining the social life can be traced back to the early periods of human history, the form of understanding of society, which we can call sociological, started with Ibn Khaldun in the 14th century, followed by Western thinkers in the 18th and 19th centuries (Karl Marx Emile Durkheim, Max Weber, etc.) is a product of developed sociological thinking. All forms of understanding, understanding and explaining the social world are valuable in their own historical and social context, whether from a religious, philosophical or scientific point of view. The common point of all these perspectives is the structure, functioning, change, etc. of the society in which we live. to understand the elements and to create a life position or intervention style accordingly. In this respect, the production or discovery of sociological knowledge is aimed at building a better and quality social world and contributing to the possibility of living. As long as one does not end the search for purpose and meaning, which is impossible. Sociological knowledge can also contribute to a more robust belief and worldview consistent with the empirical social world.

Sociology or society is a science that works on the interaction of science, society and man. Social (sociological) research extends from the relationships between different individuals who encounter on the street to the global social processes. This discipline focuses on why and how people live regularly in a society as well as how individuals or members of unions, groups or institutions live. The structure, functioning and changes of social phenomena are subject to a regular and regular causal relationship. There is no place for chance in social events. One of the important factors leading to the change of societies is the structure of knowledge in the society in question and the legitimacy of this knowledge. In other words, as the structure and content of knowledge in society change, so do societies. Since knowledge affects individual consciousness and perceptions, it will indirectly affect and direct social behaviors
\end{abstract}

Keywords: Sociology, sociological information, live sociological 


\section{Giriş}

Toplumsal hayatın anlaşılması ve açıklanmasına ilişkin görüş ve yaklaşımların tarihi her ne kadar insanlık tarihinin ilk dönemlerine kadar götürülebilirse de sosyolojik diye adlandırabileceğimiz topluma yönelik kavrayış biçimi, 14. yüzyılda İbn Haldun'la birlikte başlayan akabinde 18. ve 19. yüzyılda Batılı düşünürlerce (Karl Marx, Emile Durkheim, Max Weber vb.) geliştirilen sosyolojik düşüncenin bir ürünüdür. Topluma yönelik gerek din temelli gerek felsefi gerekse de bilimsel bakış açısıyla olsun, toplumsal dünyayı anlama, kavrama ve açıklama biçimlerinin tümü kendi tarihsel ve toplumsal bağlamında değerlidir. Tüm bu bakış açılarının ortak noktası yaşanılan toplumun yapı, işleyiş, değişim vb. unsurlarını anlama ve buna göre bir yaşam pozisyonu veya bunlara müdahale biçimi oluşturabilmektir. Bu açıdan sosyolojik bilginin keşfi de daha iyi ve kaliteli bir toplumsal dünya inşa ve yaşam imkânına katkıda bulunulmasına yöneliktir. İnsan amaç ve anlam arayışını sonlandırmadığı müddetçe -ki bu imkânsızdır- bu böyledir. Keza sosyolojik bilgi ampirik toplumsal dünyadan hareketle tutarlı ve daha sağlam bir inanç ve dünya görüşüne de katkıda bulunabilmektedir.

Sosyoloji toplumsal yapı ve insanlar arasındaki etkileşim üzerine çalışan bir bilim dalıdır. Sosyal bilimsel araştırmalar sokaktaki farklı bireyler arasındaki etkileşimlerden tutun küresel toplumsal işleyişlere kadar oldukça geniş bir alana yayılmıştır. Bu bilim, insanların nasıl ve neden toplum içinde düzenli bir şekilde yaşadıkları kadar kişilerin veya grup üyelerinin nasıl oluştuklarına da odaklanmaktadır. ${ }^{1}$

Toplumsal olguların yapı, işleyiş ve değişimleri kurallı ve düzenli bir nedensellik ilişkisine tabidir. Toplumsal olaylarda tesadüfe yer yoktur. Toplumların değişimine yol açan önemli etkenlerden biri de söz konusu toplumdaki bilginin yapısı ve bu bilginin meşruiyet gücüdür. Başka bir ifadeyle, toplumdaki bilginin yapısı ve muhtevası değiştikçe toplumlar da buna paralel olarak değişmektedir. Bilgi, bireysel bilinç ve algıları etkilediğinden dolaylı olarak toplumsal davranışları da etkileyecek ve bu davranışlara yön verecektir.

İnsan içinde yaşadığı sosyal çevresinde yaşananları anlayabilmek amacıyla bazı faaliyetlerde bulunmaktadır. Bu faaliyetler sırasında gerek günde-

\footnotetext{
${ }^{1}$ https://tr.wikipedia.org/wiki/Sosyoloji
} 
lik olsun gerekse de sistematik bilgi düzeyinde olsun, çeşitli bilgilere ulaşmaktadır. Ulaştı̆̆ı bilgiler, hem kişinin hem de toplumun çevresini kuşatmakta ve kültürel unsurlarla ilişkiye girmektedir. Bu etkileşim içerisinde toplumca benimsenmiş ve değer verilmiş olan bilgi türleri varlıklarını sürdürürken, çeşitli nedenlerle işlevselliğini yitirenler terk edilmektedirler. Bu bağlamda toplumsal yapı incelendiğinde ya da geçmişteki toplumsal yapılar hakkında yapılan çalışmaların bulguları, günümüz toplumlarının yapıları ile karşılaştırıldığında toplumların değişim aşamaları izlenebilmektedir. $\mathrm{Bu}$ değişim sürecinde, değişimi sağlayan unsurlar arasında bilgi ve bilgi türlerinin rolü ve önemi ortaya çıkmaktadır. (Sinanoğlu, 2012: 20).

$\mathrm{Bu}$ çalışmanın amacı, tarihsel süreç içerisinde ortaya çıkan toplumsal dünyayı anlama ve açıklama çabasının (teolojik, felsefi ve ya pozitif), insan ve toplum hayatına farkındalık ve nitelik sunduğunu ve sosyolojinin de böyle bir fonksiyonunun bulunduğunu ortaya koymaktır. Sosyolojik faaliyet toplumsalın her türlü bilgisini konu edindiğinden ve amacı bu toplumsal olgunun anlaşılması ve açıklaması olduğundan, üreteceği pozitif bilgi insan ve toplum hayatına bilinç ve kalite katacaktır. Bilimsel düşünce, bireylerin doğaya, tarihe ve topluma yönelik açıklama ve anlamlandırma biçiminin tezahürüdür.

Sosyoloji okumanun veya sosyolojik bilginin kişilere -mesleki unvan d1şında- ne kazandıracağı sorusu oldukça önemlidir. Bir meslek olarak sosyologluk ile bir düşünme biçimi olarak sosyolojik düşünce arasında önemli farklar vardır. İlki bazı teknik bilgi ve kuramlara dayanmakta ve kamu yönetiminin öngördüğü bir takım görevleri yerine getirmek üzerine kurgulanmıştır. İkincisi ise topluma ilişkin bir kavrayış biçimidir ki, işte bu noktada kişinin bakış açısı, zihniyet dönüşümü ve buna paralel olarak sosyal hayata ilişkin tutum ve davranış değişikliğiyle ilgilidir. Bu çalışmada daha çok sosyolojinin burada bahsi geçen ikinci boyutu üzerinde yoğunlaşılacak ve sosyolojinin bu bağlamda yaşanılabilirliği üzerinde durulacaktır.

\section{Sosyolojik Bilginin Tarihsel Gelişimi}

İnsanlığın bilim ve düşünce serüveni kuşkusuz belirli bir dönemde ve belirli bir yerde başlamış değildir. İnsanoğlu tarihin başlangıcından bugüne dek gerek kendini gerek içinde bulunduğu doğayı gerekse de içinde yaşadığı toplumu ve dönemi sürekli olarak anlamak ve açıklamak gibi bir çabanın 
içinde olmuştur. Bu çabalar farklı bölge ve dönemlerde değişik biçimlerde ortaya çıkmışsa da bilim ve bilimsel düşünce birikimi insanlığın ortak çabasının bir ürünü olarak karşımıza çıkmaktadır. Bu endenle bilim, bilimsel düşünce, ürün ve buluşlar belirli bir kişi, toplum veya dönemle sınırlandırılamaz. Bilimin evrensel kimliği bu gerçekliği açığa vurmaktadır. Keza insanoğlu yaşadığı müddetçe düşünce ve bilim tarihi de varlığını sürdürecektir (Batur, 2019, s.91)

Sosyolojinin öncüsü ve kurucusu olan İbn Haldun başta asabiyet kavramı olmak üzere, bedevi ve hadari toplum kuramları ile siyaset, ekonomi, din vb. kurumlar hakkında yapmış olduğu gözlem ve çözümlemeleriyle sosyoloji literatürüne katkıda bulunmuştur. İbn Haldun'un 14. yüzyılda sosyal bilimsel düşüncenin yapısı ve dinamikleri hakkında yapmış olduğu bilimsel çözümlemeler, Müslüman dünyada takipçisi ortaya çıkmadığından kurumsallaşamamış ve genel anlamda kendisiyle sınırlı kalmıştır. Sosyolojik düşünme, okuma ve araştırma faaliyetleri farklı bir tarzda da olsa 16. yüzyıldan itibaren Batı dünyasında yeniden ortaya çıkmış ve gelişmeye devam etmiştir (Batur, 2019, s.93)

Toplumsal olguların ve olayların açıklanmasına ilişkin kavram, kuram ve yaklaşımlar çok daha eski dönemlere götürülebilirse de modern anlamda sosyolojik bilgi, İbn Haldun'dan sonra, Batı'da yaşanan Rönesans, Reform, Fransız İhtilali, Sanayi Devrimi, Aydınlanma vb. bir takım tarihsel ve toplumsal değişim faktörlerinin etkisi altında ortaya çıkmış ve gelişmiştir. Çağdaş sosyolojik bilgi, kentleşmiş, sanayileşmiş ve hatta küreselleşmiş modern toplumların bilimsel ele alınıslarının bilgisidir. $\mathrm{Bu}$, sosyolojinin kırsal veya geçmiş toplumlarla ilgilenmediği anlamına gelmez Sosyoloji bunlarla dolaylı olarak ilgilenir. Çünkü sosyolojik ilginin merkezinde çağdaş kentsel ve küresel toplum vardır.

Avrupa'da yaşanan sosyal, ekonomik, bilimsel gelişmelerin ve siyasi olayların akademik bir disiplin olarak sosyolojinin kurulmasında önemli bir etkisi olmuştur. Modenleşme ve sanayileşmenin toplumsal hayatta yarattığ büyük değişimi anlayıp yorumlama ve açılama ihtiyacı sosyoloji bilimininin ortaya çıkmasına zemin hazırlamıştır. Batı'da sosyoloji, kendine özgü ve özel krizine entelektüel bir karşlık olarak kurulmuştur denebilir. (Kuyucuoğlu, 2015, s.675).

Modern sosyal bilimlerin ortaya çıkışı, Fransız İhtilali'nin neden olduğu sosyal ve kültürel çalkantıların ardından ortaya çıkmıştır. Devrimin ardın- 
dan yaşanan hızlı siyasal ve sosyal dönüşüm, sosyal hayatın doğal düzen çerçevesinde ele alınmasını yetersiz bırakmıştır. Bu bağlamda çözümün, egemenlik kaynağı olarak görülen toplumun yaşadığı radikal sosyal değişimin örgütlenmesi ve rasyonelleştirilmesinden geçtiği düşünülmüştür. $\mathrm{Bu}$ değişimin kontrol edilebilmesi için değişimin toplumsal düzeyde örgütlenmesi, bu örgütlenmenin gerçekleştirilebilmesi için de değişimin incelenmesi ve bu değişime yön veren yasaların keşfedilmesi ve anlaşılması gerekiyordu. Sonuçta yeni bir toplumsal düzen ihtiyacı hasıl olmuştu ve bu düzenin istikrarı için kesin bilgileri sağlayacak olan sosyal bilimlerdi. Bu bilimleri doğuran temel etken, işte bu ihtiyaçtı. (Bayram, 2009, s.17-18).

Modern sosyoloji her ne kadar Batı'da ve Batı'nın toplumsal sorunlarına çare bulmak için ortaya çıkmışsa da, günümüzde hemen hemen her ülkenin üniversitelerinde sosyoloji bölümleri ve sosyolojik araştırmalar mevcuttur. Modernleşme ve küreselleşme dinamikleri sosyal bilimlerin de yayılmasını ve küresel ölçekte kabul görmesini sağlamıştır. Modern sosyoloji, başta Batı toplumlarını anlama ve açıklama güdüsüyle hareket etmiş olmasına rağmen, bugün her toplum kendi sosyolojik araştırma ve incelemesini yapmak durumundadır. Böyle bir araştırma ve inceleme sonucunda ortaya çıkan sosyolojik bilgi ve bulgular, gerek bireysel gerekse de toplumsal alandaki bilincin gelişmesine önemli katkılarda bulunacaktır.

Geçmiş veya modern öncesi toplumların, toplumsal olgu ve olaylara ilişkin açıklama biçimleri daha çok mitolojik, felsefi ve dinsel idi. Bilim, bu açıklama biçimlerinde dolaylı olarak yer almaktaydı. Dolayısıyla da geleneksel toplumlar ağırlıklı bir şekilde felsefi, mitolojik ve dinsel toplumsal anlama ve açıklama biçimlerine sahiptiler. Bu yapı tarihsel bağlamında son derece yararlı ve işlevsel idi. Başka bir ifadeyle, günümüzde sosyolojik bilginin sağladığ1 yarar ve yerine getirdiği işlevi, geçmişte mitoloji, felsefe ve din yerine getirmekteydi.

Tarihi kaynaklar, bireysel olmaktan çok kolektif unsurlar taşıyan ilk bilgilerin mitoloji ve inançlarla birlikte kullanıldığını tespit etmişlerdir. En eski toplumlar ulaştıkları din, efsane ve büyü ile karışmış kestirme bilgileri ihtiyaçları doğrultusunda değerlendirmişler, toplumların kültürel dokularının örülmesi ve değişiminde rol oynamışlardır. (Sinanoğlu, 2012, s.20).

Ortaçağ dönemlerinde de toplumsal bilginin oluşumunda mitoloji, felsefe ve din etkinliğini sürdürmekteydi. Ancak, bu dönemde, özellikle Batı'da Hristiyanlığın yönlendirdiği ve şekillendirdiği toplumsal bilgi yapısına yö- 
nelik çeşitli eleştiri ve sorgulamalar ortaya çıkmaya başlamıştır. Rönesans ve reformun ilk adımlarının da atıldığı bu dönem, deney ve gözleme dayalı bilgi teorisinin temellerinin de atıldığı bir dönem olmuştur.

Orta çağ Batılı toplumlarda, ilerleyen zaman diliminde Hristiyanlaştırılmış antik düşünce eleştirilere maruz kalmıştır. Bu eleştiri safında yer alan düşünürler, Doğu ve İslam coğrafyasından aktarılan bilgilerin katkılarıyla, insanın iç yapılanması ve doğa ile olan ilişkilerinde yenileşmeyi ön plana alarak, kendilerine özgü bir bilgi-yöntem anlayışı geliştirerek, toplumsal düşüncenin yeniden biçimlenmesi için bir çaba içerisinde görünmektedirler (...). Empirist-septikler, doğuştan bilgi olamayacağı görüşüyle, insan idrakini aşan bilgilerle uğraşılmaması gerektiğini ifade etmek istemişlerdir. $\mathrm{Bu}$ anlayışın toplum içerisinde yaygınlaşması ile beraber, Batılı toplumların doğadaki olayları sistematik bir biçimde gözlemlemeye başladıkları anlaşılmaktadır. (Sinanoğlu, 2012, s.23).

Geçmişte, pozitif anlamda, sistematik bir deney, gözlem, analiz, sentez, istatistik vb. süreçler yoktu. $\mathrm{Bu}$ araştırma ve inceleme biçimleri modern dönemlerin bilgi teorisini oluşturmaktadır. Günümüzde felsefe, din ve mitoloji varlıklarını yer yer sürdürseler de bilimsel bilginin ortaya çımasıyla farklılaşmakta ve konumlarını yeniden gözden geçirmektedirler. Somut olguların (doğa ve toplum) incelenmesi doğa ve toplum bilimlerine devredilirken din ve felsefe belki de asli fonksiyonlarına dönmektedirler. Başka bir ifadeyle geçmişte tüm bilgileri şemsiyesi altına alan din ve felsefe tarihsel süreç içerisinde, bilimsel bilginin ortaya çıkması ve böylece kurumsal farkl1laşması sonucunda, bu alanları bilime devrettiklerini söyleyebiliriz. Bilimsel bilgi çağdaş toplumların gerek bireysel gerekse de toplumsal düzlemde temel bilgi kaynağı konumuna gelmiş bulunmaktadır. İnsanlık tarihinin toplumsal kavrayışa ilişkin olarak günümüzde ulaştı̆̆ı sosyal bilimsel düşünce düzeyinin temelde sosyoloji okuruna ve camiasına nasıl bir katkıda bulunabileceğine değinilmesi ve bunun analiz edilmesi gerekmektedir.

\section{Sosyolojik Yaşamak}

Bilginin insan hayatına biçim ve yön verme kabiliyeti herkes tarafından bilinmektedir. Sosyolojide bilgi sosyolojisi dalının çıkış kaynağı da zaten budur. İnsan eylemlerine yön veren bilgiler ister dini, ister felsefi isterse de bilimsel kaynaklı olsun, bu açıdan bilgiler insani eylemlere rehberlik etme 
niteliğine sahiptir. Geçmişte, bu rehberlik, ağırlıklı olarak din, mitoloji ve felsefe üzerinden yerine getirilmekteydi. Bilimlerin gelişmesiyle, özellikle de sosyal bilimlerin gelişmesiyle, bu rehberlik dizisine bilimler de dâhil oldular. Bu noktada konumuz açısından sosyoloji biliminin sağladı̆̆ı pozitif bilginin bireysel ve toplumsal alanda yararlılığı ve uygulanabilirliği üzerinde yoğunlaşmak gerekir.

Deney ve gözleme dayalı pozitif bilimler özellikle Batı'da gelişme ve yayılma imkânı bulmuş, daha sonra ise bu bilim ve bilgiler hızla küreselleşmeye başlamışlardır. Bunun sonucunda sosyal bilimler ve sosyoloji de toplumsal olguların ve olayların hem anlaşılması hem de açıklanmasında temel referans kaynağı olmuştur. Bu durum özellikle Batılı toplumlarda ve kültürlerde belirgindir. Batı'da sosyolojinin sağladığı yararlar ve yerine getirdiği işlevlerden tüm dünya toplumları da etkilenmiş ve böylece sosyoloji küresel bir bilim ve etkinlik haline gelmiştir.

Entelektüel izleri Rönesans ve Aydınlanma'ya dek uzanan modern dönemin bilimsel gelişmeleri, insan aklının her şeyi daha iyiye doğru değiştirebileceği inancını güçlendirmişti. Doğada doğa bilimlerinin rehberlik edeceği bu değişim, toplumsal alanda sosyal bilimler tarafından yerine getirilecekti. Oldukça geniş bir literatüre sahip olan modernleşme ister tarihsel bir olay ister sosyal bir proje olarak ele alınsın bilimler, modernlik olgusunun önemli bileşenleri arasında yer almıştır (Bayram, 2009, s.2).

Modern birey-toplumun oluşumunda pozitif bilimlerin yeri ve önemi yadsınamaz. Hangi inanç, din, felsefi görüş olursa olsun, pozitif sosyal bilimler ve sosyoloji, birey ve toplum hayatına ciddi anlamda katkılar sunmaktadır. Bu katkılar, hem bilişsel hem de eylemsel düzlemde kendini göstermektedir. Zaten, diğer tüm bilimlerde olduğu gibi sosyolojiden de bu beklenmekte ve beklenmelidir de. Bir bilimsel faaliyet birey ve toplum hayatına ışık tutmakla, insanın hayatı anlamlandırma faaliyetine katkıda bulunmakla ve sağlıklı ve tutarlı bir yaşam sürmesine katkıda bulunmakla önem ve değer kazanır. Bu husus tüm bilgi yapıları için de geçerlidir. Başka bir ifadeyle, sosyoloji, insanın nasıl yaşaması gerektiğine yönelik, dinsel veya ahlaki bir vaazda bulunmaz ancak içinde bulunduğu ve sürdürdüğü hayatının toplumsal yapısını, kültürel değerlerini, tarihsel değişimleri kavram, kuram ve yaklaşımlar aracılığıyla daha bilinçli ve kaliteli bir hale getirmesine katkıda bulunabilir. Hayatı bilinçli bir biçimde yaşamanın gösterilen çabaya değdiğini düşünen herkes için sosyoloji hararetle sıkılan bir yardım 
eli olacaktır (Bauman, 2016, s.25). Bu, sosyolojinin insanlı̆̆ın tüm sorunlarını çözeceği iddiasını taşımaz, aksine, sosyoloji toplumsal hayatı olduğu gibi çözümlemekle, yaşanılan toplumsal dünyayı daha görünür kılmakta ve böylece farkındalığı arttırmaktadır. Sosyoloji toplumun yapısını, temel dinamiklerini, toplumsal kurum, değişim, kültür, din, ahlak, sanat, hukuk vb. unsurların bilimsel yolla çözümlemekle kişiye, sosyal-varoluşsal imkan, sınır ve seçeneklerini göstermeye yardımcı olur. Bu anlamda sosyoloji topluma ve tarihe ş̧ık tutan fener gibidir. Sonuçta sosyoloji insan dünyası hakkında bir düşünme biçimidir (Bauman, 2016, s.17). Bu yolla kişi önünü daha geniş açıdan, sağlıklı ve doğru bir şekilde görebilir.

Sosyolojik tahayyül gücünün ilk verimi -ve onu meydana getiren sosyal bilimin ilk dersi- bireyin yalnızca kendisini yaşadığı dönem içerisinde konumlandırarak kişisel tecrübesine anlam verebileceği ve geleceğini tayin edebileceği, yalnızca kendi durumundaki diğer bütün insanların sahip olduğu fırsatlardan haberdar olarak kendi yaşam fırsatlarını öğrenebileceği düşüncesidir (Mills, 2019, s.16).

İnsanların sosyoloji bilimini ansiklopedik bir şekilde; toplum, toplumsal kurumlar, yapı, grup, statü, rol vb. temel kavramlarla anımsaması bu bilime haksızlık yapmaktır. Çünkü sosyoloji; bilhassa değişen ve dönüşen sosyal yaşamın niteliklerini ve aktörlerini geçmiş, bugün ve gelecek bağlamlarıyla anlama, kavrama ve açıklama becerisi kazandırmada oldukça önemli bir entelektüel zemini bireylere aktarma gibi önemli bir işleve sahiptir. Epistemolojik olarak oldukça kapsamlı bir bilişsel alana ve vizyona sahip olan sosyoloji, farklı alanları kendine özgü bilimsel yaklaşımlarıyla inceleyebilmekte ve yaptığı analizlerle toplumsala dair bilimsel veriler üretebilmektedir. Sosyolojinin bu önemi üretebildiklerine ve üretiminin toplumsalın açıklanmasındaki efektif katkılarına bağlı olarak gerçekleşmektedir (Eraslan, 2011, s.2).

Sosyolojik okuma ve düşünme sadece sosyoloji lisansı gören öğrenciler için değil herkes için toplumsal bir aydınlanma ve anlama kaynağı olmalldır. Çünkü herkes, toplum içinde yaşamak, diğerleriyle ilişki kurmak ve çeşitli roller yerine getirmek zorunda olduğu için, sosyolojik bilgi her meslek için yararlıdır. Söz gelimi gazetecilik, öğretmenlik, avukatlık, din adamlığı, satıcılık, iş yönetimi, siyaset gibi pozisyonlar insanlarla ilgilenen mesleklerdir. Bunlar toplumdaki insan ilişkileri konusunda sıradan bilgiden daha fazlasını gerektirirler. Hatta sıradan aile, komşuluk ve diğer grup içi 
ilişkiler dahi sosyolojik bilgi üzerine bina edildiğinde daha başarılı sonuçlar verebilir (Fichter, 1997, s.15).

Öte yandan sosyal bilimler, salt toplumsal dünyanın doğası, yapı ve işleyişiyle sınırlı kalmamıştır. Sosyoloji, toplumsal olguların nesnel incelemesi olduğu kadar kültürel değerlerin de toplumsal hayattaki yerini incelediğinden, bu inanç ve değerler de sosyolojik ilgiden bağımsız değildirler. Sosyolojinin toplumsal değerlere olan ilgisi, iyi-kötü- ve ya doğru-yanlış şeklindeki ahlaki bir ilgi olmayıp, bu değerlerin bireysel-sosyal hayattaki yeri, önemi ve işlevi şeklinde olmaktadır. Dolayısıyla, bu açıdan, toplumsal inanç ve değerler de sosyolojik bir inceleme konusu olmaktadırlar (Bayram, 2009, s.10). Kültürel görecelik, dini ve ahlaki farklılıkların tarihsel ve toplumsal kökenlerine değinmekle sosyoloji bu açıdan da kişiye önemli bakış açıları kazandirır.

Toplumsal tüm düşünüş ve davranışlar belirli bir amaç, inanç, değer, bilgi vb. bir kaynaktan beslenirler. Çünkü akıl sahibi olmak (insan) bunu gerektir. Bu sav, insanın biyolojik varlığını yadsımaz. Biyolojik yasalar hükmünü zorunlu olarak (gayri iradi) icra ederler. Kişi doğa yasalarına uymadığında anında karşılığını görür. Sosyal bilimsel yasalar ise doğa yasalarından ziyade hukuk yasalarına benzer. Uyduğunda fayda uymadığında ceza görmen büyük olasıdır.

Bilimsel bilginin ayırt edici niteliği, daha çok akla dayan(dırma)ması şeklinde ortaya çıkmaktadır. Bu önermeden diğer bilgilerin akla dayanmadığı sonucu çıkarılmamalıdır. Arada bir nüans vardır. Bilimsel bilgi deney ve gözlem çerçevesinde salt akla dayanmakta ve konusu somut olgulardir. Diğer bilgilerde akıl, daha çok ikincil düzeyde kalmaktadır. Felsefe de salt akla dayanmakla birlikte normatif niteliğinden ve daha çok soyut-ahlaki konularla ilgilendiğinden dolayı bilimsel bilgiden ayrılmaktadır. Bu bağlamda, çağdaş toplumlarda bilimsel bilgi vazgeçilmez ve başat bir bilgi kaynağı olarak kendini göstermektedir. Öte yandan, sosyoloji, bilgi üretim etkinliğinde bulunurken, toplumsal değerleri etkilediği gibi bu değerlerden de etkilenmektedir. Bu etkileşim, sosyolojik faaliyetin doğasında mevcuttur. Sosyolojinin araştırma nesnesi kabaca toplum ve kültür olmasından dolayı sosyolojik bakış, bir taraftan toplumu ve kültürü etkilerken kendisi de bunlardan etkilenmektedir. Bu etki, kendisini kavram, kuram, yaklaşım, paradigma vb. oluşturma düzleminde göstermektedir. 
Bilimsel bilginin en önemli niteliklerinden biri olan rasyonel gerekçelendirme ve bu gerekçelendirmenin dayandığı akıl, bilim ve toplum ilişkisi doğal olarak bizi Aydınlanma olgusuna götürür. Aydınlanma düşüncesi, en genel anlamıyla aklı, bilhassa özgürleşme adına insan hayatının tüm boyutlarında uygulanması gereken bir unsur olarak görmüştür. Dolayısıyla bu çağın düşünürleri, batıl inanç ve dogmaların karşıtı olarak aklın, özgür ve adil bir toplum için mutlak bir temel oluşturduğuna inanmışlardı. Bu çerçevede sosyal bilimlere merkezi bir rol verilmişti. Osborne, sosyal bilimleri iki açıdan Aydınlanmayla ilişkilendirmektedir: Aydınlanmanın özneleri olarak sosyal bilimler ve modern toplumların aydınlanacak nesnesi olarak sosyal bilimler. Yani sosyal bilimler aydınlanmanın hem öznesi hem de nesnesi idiler (Bayram, 2009, s.8).

Bilim ve toplum ilişkisine baktığımızda, geçmiş dönemlerde daha çok toplum merkezli, uzmanlaşmamış, farklılaşmamış ve bilimin görece daha pasif ve yönlendirilen bir konumu vardı. Oysa modern toplumların uzmanlaşmış ve farklılaşmış yapılarında bilim daha aktif ve yön veren bir konuma ulaşmıştır. Bilimler arasında gündelik sosyal hayata dokunan sosyolojinin yeri de bir hayli önem kazanmıştır. Günümüzde, ister doğrudan isterse de dolaylı olsun, yoğunluğu değişebilmekle birlikte, hemen hemen her birey sosyolojik kavram, kuram, yaklaşım, araştırma vs. olgularla karşılaşmaktadır. Bu açıdan sosyolojik bilgi ve bulgularla temas modern bireyin kaçınamayacağı bir olaydır.

Toplum, bilimlerin ortaya çıktığı kabul edilen Antik Yunan döneminden bu yana, bilimin yönelimini belirlerken, özellikle sanayi toplumlarında bilim de toplumu etkilemeye başlamıştır. Bu etkilemede merkezi rol sosyal bilimlere aittir. Sosyal bilimlerin temel araştırma birimi kişilerdir (sosyal bireyler); çünkü kişiler (sosyal bireyler), sosyal dünyada olup biten her şeyin nedenidirler. Bilindiği üzere sosyal bilimler sosyal dünyadaki süreç ve işleyişleri anlama ve açklama çabasındadırlar. Bu çabada sosyal bilimcinin, toplum üyelerinin kendi dünyalarıyla ilgili anlayışlarının ötesine geçmesi ve kavrayışın yeterliliğini sorgulaması gerekmektedir. Sosyal süreçler, üyelerin (grupların) eylemlerinin ürünü olduğundan ve üyelerin bu süreci, yanlış anlama ihtimalleri bulunduğundan bu açıdan sosyal bilim, potansiyel olarak aydınlatıcı ve özgürleştirici bir rol üstlenebilir. (Bayram, 2009, s.14-15).

Sosyolojik bilgi, sosyal yaşam dünyasına sarmal olarak girer ve çıkar; bu sürecin tamamlayıcı bir parçası olarak hem kendini hem de söz konusu 
dünyayı yeniden şekillendirir. (...). Ayrıca sosyal bilimlerin ve sosyal kuramların uygulamadaki etkisi de oldukça büyüktür ve sosyolojik kavram ve bulgular modernliğin ne olduğu konusuna yapıcı şekilde dahil olmaktadırlar (Giddens, 2014, s.23).

Sosyolojik bilgi ve bulgular, sadece, bireysel anlamda kişinin düşünce ve davranışlarına olumlu yansımaz, aynı zamanda devletlerin sosyal politika ve planlama çalışmalarına da katkıda bulunur. Sosyolojik bilginin, toplumsal sorun çözebilme, toplumsal müdahale ve diğer toplumsal içerikli çalışma alanlarında da, özellikle uygulayıcılara önemli yararlar sağlamaktadır (Batur, 2011, s.169). Günümüzde başta gelişmiş ülkeler olmak üzere, hemen hemen tüm ülkeler yönetim ve planlama işlerinde sosyolojik bilgi ve araştırmalardan yararlanmakta ve bu sayede daha başarılı olabilmektedirler. Böylece sosyolojik bilgi hem bireysel hem de toplumsal düzlemde yararlı etkisini gösterebilmektedir.

Politika-yapımına yönelen bilimlere uygulamalı bilimler denir. Buradaki amaç temel bilimler alanında üretilen bilimsel bilgiyi doğanın ya da toplumun bir sorununun çözümü için kullanabilmektir. Politika-yapıcı sosyolog için öncelikle önemli olan hayatın içinde ortaya çıkan sosyal sorunlara, bazen alet çantasını bazen de doktor çantasını kullanarak çözümler üretebilmektir. Sosyologun doktor çantasını kullanması, onun hayata organizmacı bir yaklaşımla yaklaştığı ve kendisini de toplum doktoru gibi gördüğü anlamına gelmektedir. Alet çantasını kullanması ise hayatı mekanik bir yapı olarak gördügüne işarettir; bu örnekteki sosyolog ise kendini toplum mühendisi gibi görmektedir. (...). Politika-yapıcı sosyolog üretilen bilimsel bilgiyi sorun alanına taşımakla, sorunun çözümünde bir araç olarak kullanmakla, dolayısıyla bilgiyi hayata uygulamakla görevlidir. Politika-üretim etkinliği, kamu kaynakları kullanılarak yürütülen bilim etkinliğinin topluma olan borcunu kısa vadede ödemenin bir yoludur. Politika-üretim etkinliği büyükten küçüğe ve doğal, sosyal ve teknik her boyut ve düzlemdeki hayat alanına akli ve ahlaki bir müdahaledir denebilir. (Çelebi, 2008, s.71).

Toplumsal mühendislik faaliyeti, sosyolojik bilginin toplumsal hayata uygulanmasıyla ilgilidir. Eskiden pek çok sosyal planlama deneme-yanılma veya tahminlere dayalı bir şekilde gerçekleştirilmiştir. Her aile, dini kurum, okul, işyeri, dernek ve belediye geleceğe ilişkin planlamalar üzerinde çalışır, sorunların çözmeye yönelir, personelini eğitir ve sosyal hedeflerini belirler. $\mathrm{Bu}$, toplumsal mühendislikten başka bir şey değildir. Bu işlevleri gelişigü- 
zel, deneme-yanılma yöntemleri yerine, sosyolojinin sağladığı rasyonel ve geniş bilgi temeli üzerine kurmak daha akıllıca ve daha verimli olabilir (Fichter, 1997, s.15).

Sosyolojinin modern toplumsal hayatta oynadığı önemli rol, modern kültürün bilimsel düşünceyle olan ilişkisinden kaynaklanmaktadır. Modern kültürün önemli bileşenlerinden biri de rasyonel düşünce biçiminin başat konumda olmasıdır. Bu haliyle rasyonel düşünce, sosyolojik davranışın da çıkış noktasını oluşturmaktadır. Son aşamada, toplumsal hayata yönelen sosyolojik ilgi ile modern kültürün rasyonel karakteri arasında doğrudan bir ilişki bulunmaktadır.

Sosyolojinin modernliğin düşünümselliğindeki esas yeri, modern toplumsal yaşam üzerindeki en genel düşünce türü olarak oynadığı rolden ileri gelmektedir. (...). Sosyoloji ile diğer toplum bilimlerinin kavram, kuram ve bulguları, sürekli biçimde, ilgili oldukları alanların içine girip çıarlar. Bunu yaparken de sosyolojik düşünceyi kendiliğinden öğrenmiş olan inceleme konularını düşünümsel olarak yeniden yapılandırırlar. Dolaysıyla modernliğin kendisi aslen ve derinden sosyolojiktir (Giddens, 2014, s.46-47).

\section{Sonuç}

Genelde sosyal bilimlerin, özelde ise sosyolojinin birey ve toplum hayatındaki yeri ve önemine değinilen bu çalışmada, sosyolojik araştırma, inceleme ve düşünme sonucunda elde edilen sosyolojik bilgi ve bulguların günümüzde birey ve toplum hayatına sağladığı yararlara değinildi.

Toplumsal düşünce ve bilgilerin geçmişi çok eskilere götürülebilirse de, bu bilgi ve düşünce biçiminin sosyolojik bir düzeye ulaşması öncelikle 14 . Yüzyılda İbn Haldun'la başlamasına karşılık kurumsal ve disipliner bir faaliyet haline gelmesi ise yakın zamanların (19. yy.) bir ürünü olmuştur. Başka bir ifadeyle toplumsal düşünce ve bilgiler geleneksel ve geçmiş toplumlarda daha çok görgül veya felsefi bir düzlemde iken, sosyolojik düşünme ve bilgi biçimi modern toplumların bir niteliği olarak karşımıza çıkmaktadır. Topluma yönelik bilişsel merak her zaman ve her yerde vardı. Ancak bu merakın bilimsel bir düzlemde gelişmesi yakın zamanların bir ürünüdür.

Toplumsal olguların ve olayların sosyolojik olarak incelenmesi ve bunun sonucunda üretilen pozitif bilginin sağladığı yararlar, hem bireysel hem de 
toplumsal yaşam alanlarında kendisini göstermektedir. Bireysel düzlemde, birey, içinde bulunduğu toplumun yapısını, kültürünü, değişim biçimini ve yönünü, başat değerleri, toplumsal normları vs. öğrenme sayesinde, -bu öğrenme sosyalizasyon sürecinde daha çok aktarılma şeklinde olmaktadır-, daha bilinçli ve tutarlı bir hayat oluşturma sürecinde önemli katkılarda bulunabilmektedir. Keza, sosyolojik bilgi, kamusal alanda da, özellikle sosyal politika ve planlama çalışmalarında sağladığı bilimsel bilgi sayesinde, daha akıllıca ve başarılı adımların atılmasında önemli bir rol üstlenebilmektedir.

Nihayet, sosyolojik yaşamak, modern toplumlarda yaşayan insanların sosyal bilimsel bilgi ve bulgular ışığında bireysel ve toplumsal yaşamını sürekli gözden geçirerek, düşünümsel bir çerçevede, içinde bulunduğu ve yaşamını sürdürdüğü toplumsal dünyanın özfarkındalığını arttırmak, yönünü belirlemek ve kalitesini yükseltmek anlamına gelmektedir. Sosyolojinin sağlayabileceği tüm bu yarar ve katkıların ortaya çıkabilmesi için, insanların ve toplumların sosyolojik yaşamaya karar vermesine bağlı olduğunu da belirtmek gerekir. 


\title{
EXTENDED ABSTRACT
}

\section{$\underset{*}{\text { Sociological Living }}$}

\author{
Behçet Batur \\ University of Gaziantep Islam, Science and Technology
}

Although the history of views and approaches to understanding and explaining social life can be traced back to the early periods of human history, the way of understanding society, which we can call sociological, started with Ibn Khaldun in the 14th century, followed by Western thinkers in the 18th and 19th centuries (Karl Marx, Emile Durkheim, Max Weber etc.) is a product of sociological thought developed. All forms of understanding, understanding and explaining the social world, whether from a religious, philosophical or scientific point of view, are valuable in their own historical and social context. The common point of all these perspectives is the structure, functioning, change and so on of the society we live in. to understand the elements and to form a life position or a way of interfering with them accordingly. In this respect, the discovery of sociological knowledge is aimed at contributing to the possibility of building a better and better social world and living. As long as man does not end his search for purpose and meaning, which is impossible, this is so. Likewise, sociological knowledge can contribute to a coherent and stronger belief and worldview, based on the empirical social world.

Human beings carry out some activities in order to understand what happens in the social environment in which they live. During these activities, he / she reaches various information, whether on a daily basis or at a systematic level of knowledge. The information it reaches encompasses the environment of both the person and the society and interacts with cultural elements. While the types of knowledge that are adopted and valued by society survive in this interaction, those who lose their functionality for various reasons are abandoned. In this context, when the social structure is examined or the findings of the studies about the social structures in the past are compared with the structures of today's societies, the stages of change of societies can be traced. In this process of change, the role and im- 
portance of information and information types among the factors that provide change emerge.

The question of what sociology reading or sociological knowledge will bring to people - other than professional titles - is very important. There are important differences between sociologist as a profession and sociological thinking as a way of thinking. The first is based on some technical knowledge and theories and is built on fulfilling a number of duties stipulated by the public administration. The second is a way of understanding about society, at this point it is related to the person's perspective, mentality transformation and parallel to this, the change of attitude and behavior towards social life. In this study, the second dimension of sociology mentioned here will be focused on and the livability of sociology in this context will be emphasized.

Although the history of social thought and knowledge can be traced back to very old times, the fact that this knowledge and way of thinking reached a sociological level began with Ibn Khaldun in the 14th century but became an institutional and disciplinary activity in recent times (19th century). In other words, while social thoughts and knowledge are on an empirical or philosophical level in traditional and past societies, sociological thinking and knowledge form emerges as a characteristic of modern societies. Cognitive curiosity towards society has always been present everywhere. However, the development of this curiosity on a scientific level is a product of recent times.

The sociological examination of social facts and events and the benefits provided by the positive information produced as a result are manifested in both individual and social life spheres. At the individual level, the individual knows the structure, culture, mode and direction of change, dominant values, social norms etc. Through learning - this learning is more in the form of being transferred in the socialization process - it can make important contributions to the process of creating a more conscious and coherent life.

Finally, sociological life means increasing the self-awareness of the social world in which they live and live, in a reflexive framework, by constantly reviewing the individual and social life of people living in modern societies in the light of social scientific knowledge and findings, determining its direction and improving its quality. It should also be noted that for all these 
benefits and contributions that sociology can provide, it depends on the decision of people and societies to live sociologically.

\section{Kaynakça / References}

Batur, B. (2019). Bilim tarihinde bir dönemeç: İbn Haldun'da sosyal bilim düşüncesinin doğuşu. Antakiyat, 2(1), 90-115.

Batur, B. (2011), Sosyal devlet bağlaminda sosyal politika ve projelerin sosyolojik bir incelemesi. Yayımlanmamış Yüksek Lisans Tezi, Gaziantep Üniversitesi, Sosyal Bilimler Enstitüsü.

Bauman, Z. (2016). Sosyolojik düşünmek. çev: A. Yılmaz, İstanbul: Ayrinti Yayınları.

Bayram, A. K. (2009). Modernlik ve sosyal bilimler: Bilgi, iktidar, etik ve toplum. Afyon Kocatepe Üniv. Sosyal Bilimler Dergisi, 11(1), 1-26

Çelebi, N. (2008). Sosyoloji sosyologun yaptı̆g ise. H.Ü. Türkiyat Araştırmaları, 8, 69-80..

Eraslan, L. (2011). Sosyolojik metaforlar. Akademik Bakış Dergisi, 27, 1-22

Fichter, J. (1997). Sosyoloji Nedir?, Çev: N. Çelebi, Ankara: Attila Kitapevi

Giddens, A. (2014). Modernliğin Sonuçları, çev: Ersin Kuşdil, İstanbul: Ayrıntı Yayınları

Kuyucuoğlu, İ. (2015). Sosyolojinin kuruluşunu etkileyen düşünce akımları ve sosyolojide yöntem tartışmaları. Uluslar arası Sosyal Araştırmalar Dergisi, 8(36), 674-687

Mills, C. W. (2019). Sosyolojik tahayyül. çev: Öç Küçük, İstanbul: Hil Yayınları.

Sinanoğlu, A. F., (2012). Sosyo-kültürel yapının biçimlenmesinde bilginin rolü. Batman University Journal of Life Sciences, 1(1), 19-27

\section{Kaynakça Bilgisi / Citation Information}

Batur, B. (2021). Sosyolojik yaşamak. OPUS-Uluslararası Toplum Araştırmaları Dergisi, 17(37), 4721-4737. DOI: 10.26466/opus.736124 